University of Nebraska - Lincoln

DigitalCommons@University of Nebraska - Lincoln

USGS Staff -- Published Research

US Geological Survey

2016

\title{
Coherent late-Holocene climate-driven shifts in the structure of three Rocky Mountain lakes
}

Jeffrey R. Stone

Indiana State University, jeffery.stone@indstate.edu

Jasmine E. Saros

University of Maine, jasmine.saros@maine.edu

Gregory T.Pederson

U.S. Geological Survey, gpederson@usgs.gov

Follow this and additional works at: http://digitalcommons.unl.edu/usgsstaffpub

Part of the Geology Commons, Oceanography and Atmospheric Sciences and Meteorology Commons, Other Earth Sciences Commons, and the Other Environmental Sciences Commons

Stone, Jeffrey R.; Saros, Jasmine E.; and Pederson, Gregory T., "Coherent late-Holocene climate-driven shifts in the structure of three Rocky Mountain lakes" (2016). USGS Staff-- Published Research. 898.

http:// digitalcommons.unl.edu/usgsstaffpub/898

This Article is brought to you for free and open access by the US Geological Survey at DigitalCommons@University of Nebraska - Lincoln. It has been accepted for inclusion in USGS Staff -- Published Research by an authorized administrator of DigitalCommons@University of Nebraska - Lincoln. 


\title{
Coherent late-Holocene climate-driven shifts in the structure of three Rocky Mountain lakes
}

The Holocene

I-9

(C) The Author(s) 2016

Reprints and permissions:

sagepub.co.uk/journalsPermissions.nav

DOI: I0.II77/09596836I6632886

hol.sagepub.com

\author{
Jeffery R Stone, ${ }^{1,2}$ Jasmine E Saros ${ }^{2,3}$ and Gregory T Pederson ${ }^{4}$
}

\begin{abstract}
Large-scale atmospheric pressure centers, such as the Aleutian and Icelandic Low, have a demonstrated relationship with physical lake characteristics in contemporary monitoring studies, but the responses to these phenomena are rarely observed in lake records. We observe coherent changes in the stratification patterns of three deep $(>30 \mathrm{~m})$ lakes inferred from fossil diatom assemblages as a response to shifts in the location and intensity of the Aleutian Low and compare these changes with similar long-term changes observed in the $\delta^{18} \mathrm{O}$ record from the Yukon. Specifically, these records indicate that between 3.2 and I.4 ka, the Aleutian Low shifted westward, resulting in an increased frequency of storm tracks across the Pacific Northwest during winter and spring. This change in atmospheric circulation ultimately produced deeper mixing in the upper waters of these three lake systems. Enhanced stratification between 4.5 and $3.3 \mathrm{ka}$ and from I.3 ka to present suggests a strengthened Aleutian Low and more meridional circulation.
\end{abstract}

Keywords

diatoms, Holocene, paleoclimate, paleolimnology, Rocky Mountains, stratification

Received 6 July 2015; revised manuscript accepted 19 December 2015

\section{Introduction}

Wintertime atmospheric circulation in the northern hemisphere is profoundly influenced by the Aleutian Low (AL) and Icelandic Low. These low-pressure cells are seasonally interdependent atmospheric processes, with an inter-annual oscillation pattern that is seesaw-like in nature (Honda et al., 2001; Overland et al., 1999; Rodionov et al., 2007). Because of the influence of these semi-persistent low-pressure cells on stationary flow patterns and the position of migratory major storm tracks, they have a significant impact on long-term climate patterns. The closely associated teleconnective climate indices of the Pacific-North America (PNA) pattern and the North Atlantic Oscillation (NAO) are linked to ecological phenology in modern lakes (Adrian et al., 2006; Gerten and Adrian, 2001; Straile et al., 2003) and are often attributed to paleolimnological patterns sharing similar spectral frequencies (Ólafsdóttir et al., 2013; Stevens et al., 2006). However, the response among North American lakes is mixed, showing limited regional coherence (Barron and Anderson, 2011; Jones et al., 2001; Katsuki et al., 2009; Nõges et al., 2010) although they are influenced by the same atmospheric processes.

The intensity and position of the Aleutian low-pressure center exerts a major influence on the climate of the North Pacific and western North America (Overland et al., 1999; Rodionov et al., 2005). The AL is a seasonally persistent Northern Hemisphere atmospheric circulation pattern that forms over the North Pacific during the cool season (September-May). The unstable mean flow extending from the AL generates transient storm systems, which are carried across North America along the axis of the westerly jet core or the prevailing storm track (Rodionov et al., 2007; Wise, 2012). On decadal and longer time scales, the intensity and position of the AL shifts, which influences the routing of winter season storm tracks across western North America. This is reflected in the long-term variability of the North Pacific Index (NPI) and in the sign of the Pacific Decadal Oscillation (PDO) (Chhak et al., 2009; Schneider and Cornulle, 2005). When shifted eastward and intensified, the AL enhances meridional flow, which routes storms along the North American coast and northward, into the Gulf of Alaska (Figure 1). During weakened (westward) shifts in the AL, meridional flow is weakened, zonal flow intensifies, and storms are more commonly routed into the continental interior (Rodionov et al., 2005). Decadal variability in the AL has been linked to changes in sea surface temperatures and thermocline variability in the North Pacific and, as such, has important implications for ocean ecosystems (Katsuki et al., 2009; Miller et al., 2004; Minobe, 1999), as well as patterns of drought, snowpack variability, and continental terrestrial and aquatic ecosystems (Barron and Anderson, 2011; Cayan et al., 1998; Gan, 2000; Pederson et al., 2013).

\footnotetext{
'Department of Earth and Environmental Systems, Indiana State University, USA

${ }^{2}$ Climate Change Institute, University of Maine, USA ${ }^{3}$ School of Biology and Ecology, University of Maine, USA ${ }^{4}$ Northern Rocky Mountain Science Center, U.S. Geological Survey, USA
}

Corresponding author:

Jeffery R Stone, Department of Earth and Environmental Systems, Indiana State University, Terre Haute, IN 47809, USA

Email: jeffery.stone@indstate.edu 

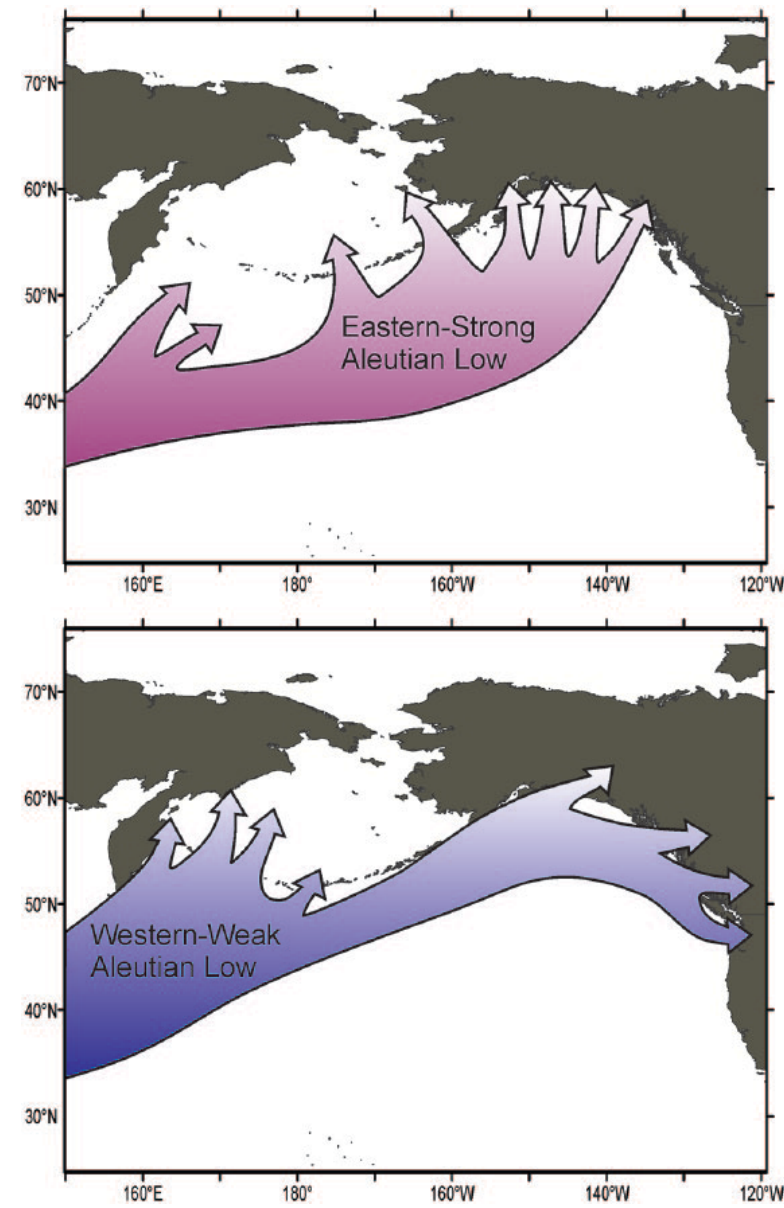

Figure I. Influence of the position and intensity of the Aleutian Low (AL) on the routing of winter storms (after Rodionov et al., 2005). Upper figure shows the eastern/strong AL, with typical storms routing mostly north into Alaska. Lower figure shows western/weak AL with storms routing into mostly west into the southern Canada and northwestern United States.

Large-scale atmospheric climate patterns have a demonstrated relationship with physical and biological processes in lakes (Blenckner, 2005; Blenckner et al., 2007; Straile and Adrian, 2000; Straile et al., 2003). Regionally coherent lake changes in response to atmospheric circulation patterns are evident in the records of surface water temperature, lake-ice phenology, and lake level in longterm lake monitoring studies (Magnuson et al., 1990, 2004, 2006). This is because physical processes in lakes often respond to solar irradiation, air temperature, relative humidity, and wind speed, which express a high level of spatial coherence due to large-scale atmospheric circulation patterns (Jones et al., 1997; Livingstone, 2008; Magnuson et al., 1990). These observations have led to a shift in perspective, from lakes primarily acting as recorders of local climate to a new paradigm of lakes serving as archives of large-scale climate forcings modified to different extents by local climate and individual lake characteristics (Adrian et al., 2009; Blenckner, 2005; Livingstone, 2008; Williamson et al., 2009).

Potential multi-decadal state changes in the AL have been identified from several paleoclimate records from the northwestern Pacific region (Anderson et al., 2005; Barron and Anderson, 2011; Chipman et al., 2012; Edwards et al., 2001; Fisher et al., 2004, 2008; Latif and Barnett, 1994). However, despite the broad region where climate is influenced by the AL, few paleolimnological records outside of the Pacific Rim display a synchronous or coherent late Holocene response. In North America, abrupt, high-magnitude climate events observed at low resolution in Holocene lake records may share broadly similar sequential patterns, but upon closer inspection are time-transgressive in nature (Walker and Pellatt, 2008; Williams et al., 2010). Long-term, high-resolution paleolimnologic archives with a high degree of regional coherence are relatively uncommon (Fritz, 2008; Fritz et al., 2000; Laird et al., 2003, 2007). This has in part been attributed to the complex and commonly non-linear ecological response of the biological indicators that are used to reconstruct past conditions (Fritz, 1996). But many other factors, such as differences in the physical, hydrological, chemical, or trophic setting of lakes; quality of age control; landscape position; and local climate influences can contribute to the difficulty of interpreting environmental history from multiple sites (Blenckner, 2005; Fritz, 2008; Webster et al., 2000; Williams et al., 2010). Interannually, climatic changes related to the strength and position of the AL likely influence the thermal structure of lakes, primarily by changing the timing and nature of lake mixing and stratification patterns (Ragotzkie, 1978). For example, when the AL intensifies and shifts eastward (e.g. a +PDO), the Pacific Northwest and northern Rockies regions experience warmer winter temperatures (Wise, 2012), which can result in fewer freezing days, more precipitation falling as rain instead of snow, decreased snow cover, and warmer spring air temperatures. Because the intensity and position of the AL also influences storm track position (Rodionov et al., 2007; Wise, 2012), increased wind frequency and intensity from storms may directly influence the convective mixing energy of the epilimnion affecting the depth of the thermocline and the timing of destratification (Ragotzkie, 1978).

The ecology of lake plankton is 'tuned' to these seasonal changes because altering the thermal structure of lakes affects nutrient cycling, physiological processes, light availability, and trophic interactions (Blenckner et al., 2007; Dröscher et al., 2009; Gerten and Adrian, 2001; Straile and Adrian, 2000). As a result, over longer periods we expect changes in the thermal structure of a lake to have an observable influence on the structure and composition of lake plankton - as recorded in their sediment records as shifts in fossil assemblages. Diatoms are single-celled golden-brown algae, with a siliceous cell wall that commonly preserves in lake sediment, found in most aquatic systems. Diatoms are highly sensitive to environmental variables and exhibit substantial capacity for exploiting ecological niches in an exceptional range of aquatic habitats (Smol and Stoermer, 2010). In particular, in lakes with low phosphorus concentrations and elevated alkalinities (Saros and Anderson, 2015), small centric diatom species of the genus Lindavia (Cyclotella) (and closely related genera, such as Discostella) are inferred to have an ecological advantage over larger diameter congeners and dense colonial plankton with higher nutrient requirements, such as Aulacoseira, when a lake is strongly stratified (Saros and Anderson, 2015; Smol et al., 2005; Wang et al., 2008). In this paper, we use several common diatom species from lakes in the northern and central US Rocky Mountain region to investigate changes in lake stratification through the late Holocene. Using fossil diatom records from three lakes located in the US Rocky Mountains, we explore longterm changes in the $\mathrm{AL}$ as a possible explanation for coherent regional responses observed in lake thermal structures and ecosystems of these lakes over the last 4000 years.

\section{Regional setting}

The lakes for this study were selected based on the abundance of cyclotelloid diatom species in the plankton (and fossil records), which were the focus of the neoecological experiments discussed in Saros et al. (2012). They can be grossly characterized as deep $(>30 \mathrm{~m})$ subalpine to alpine lakes with low nutrient concentrations and low sediment turbidity (lacking substantial glacial inputs). When possible, the sites were selected to optimize the influence 


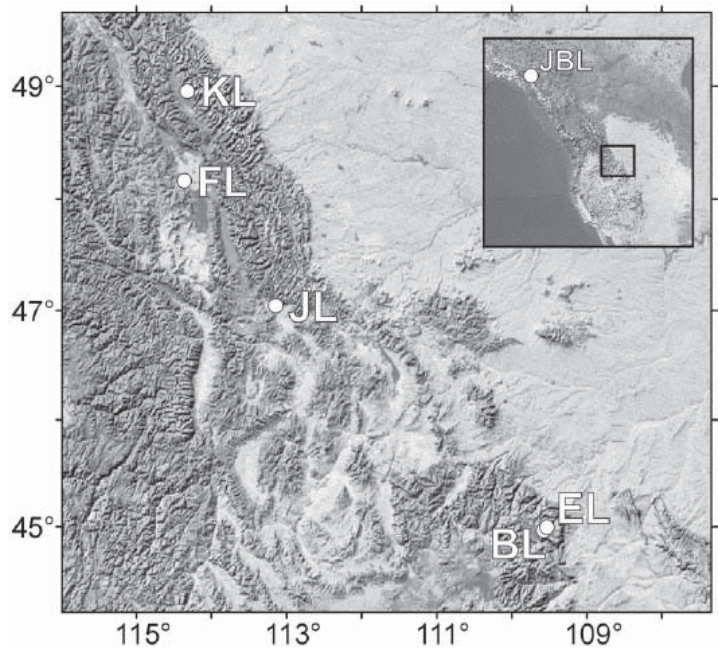

Figure 2. Map showing the location of the study lakes: Emerald (EL), Beauty (BL), and Upper Kintla (KL). Additional lake sites marked on the map and inset are discussed in the text: Foy (FL), Jones (JL), and Jellybean (JBL).

of wind intensities (large surface areas, long axes along major wind directions, few wind shelters). All three lakes have low sedimentation rates, averaging $\sim 0.015 \mathrm{~cm} / \mathrm{yr}$.

Beauty Lake $\left(44^{\circ} 58^{\prime} 12.12^{\prime \prime} \mathrm{N}, 109^{\circ} 34^{\prime} 21.08^{\prime \prime} \mathrm{W}, 2877 \mathrm{~m}\right.$ a.s.1.) and Emerald Lake $\left(44^{\circ} 59^{\prime} 49.31^{\prime \prime} \mathrm{N}, 109^{\circ} 31^{\prime} 33.81^{\prime \prime} \mathrm{W}, 2975 \mathrm{~m}\right.$ a.s.1.) are deep $(>30 \mathrm{~m})$ alpine lakes with relatively small surface areas. Both lakes are located within the Beartooth Mountain Range, just south of the Wyoming-Montana border (Figure 2). The lake catchments are characterized by sparse vegetation, shallow soils, and large expanses of exposed Precambrian granitic bedrock. Because of slow weathering rates, lakes in this region are typically dilute with low silicon $(\mathrm{Si})$ and phosphorus $(\mathrm{P})$ concentrations. These lakes are usually ice-free from early July through October (Saros et al., 2003), similar to most of the lakes in this region. Upper Kintla Lake $\left(48^{\circ} 57^{\prime} 14.25^{\prime \prime} \mathrm{N}, 114^{\circ} 19^{\prime} 9.50^{\prime \prime} \mathrm{W}\right.$, $1219 \mathrm{~m}$ a.s.1.) is located in the northern-most part of Glacier National Park, very near the US-Canada border (Figure 2). Upper Kintla Lake sits at a lower elevation and has a greater surface area, with a long, linear basin characteristic of a drowned river valley. Upper Kintla Lake has nutrient and water chemistry characteristics that are typical of many lower elevation lakes in the northern part of Glacier National Park (see supplemental information, available online; Saros et al., 2010).

\section{Methods}

Age model

Sediment cores from Upper Kintla, Beauty, and Emerald Lakes were collected from $\sim 30 \mathrm{~m}$ below the lake surface with a simple piston (Griffith) corer during the summer of 2007. Because Upper Kintla Lake is approximately $56 \mathrm{~m}$ at the deepest point, sediment cores were collected from a region nearer to the margin of the lake, whereas the other sediment cores were collected nearer to the center. Each core captures a continuous sequence of sediment ranging from 0.75 to $1.35 \mathrm{~m}$ in length (Table 1). Cores were sub-sampled in the field in contiguous $0.5-\mathrm{cm}$ increments from the sediment-water interface to the bottom of the core. Age models (Figure 3) for each core were constructed using ${ }^{210} \mathrm{~Pb}$ dating (Appleby and Oldfield, 1978) of sediment (except Upper Kintla), and ${ }^{14} \mathrm{C}$-dating of wood fragments and pine needles was recovered from the cores (Table 1) using the program BACON (2.2) (Blaauw and Christen, 2011). All radiocarbon dates were
Table I. Chronology data and materials used to create the BACON age models. ${ }^{210} \mathrm{~Pb}$ ages and error presented in calendar years (before 1950); ${ }^{14} \mathrm{C}$ ages and error presented in uncalibrated radiocarbon years.

\begin{tabular}{|c|c|c|c|c|c|}
\hline Sample & Age & Error & Depth $(\mathrm{cm})$ & Method & Material \\
\hline KNT-Surf & -57.50 & 1.00 & 0 & & \\
\hline KNT-018 & 265.00 & 25.00 & 8.75 & $14-C$ & Plant/Wood \\
\hline KNT-048 & 610.00 & 45.00 & 23.75 & $14-C$ & Plant/Wood \\
\hline KNT-066 & 1660.00 & 30.00 & 32.75 & I4-C & Plant/Wood \\
\hline KNT-I I 8 & 3210.00 & 30.00 & 58.75 & $14-C$ & Plant/Wood \\
\hline KNT-I2I & 3300.00 & 45.00 & 60.25 & $14-C$ & Plant/Wood \\
\hline EM-Surf & -57.50 & 1.00 & 0 & & \\
\hline EM-00I & -40.00 & 1.00 & 0.25 & $210-\mathrm{Pb}$ & Sediment \\
\hline EM-002 & -24.36 & 1.55 & 0.75 & $210-\mathrm{Pb}$ & Sediment \\
\hline EM-003 & -8.73 & 1.55 & 1.25 & $210-\mathrm{Pb}$ & Sediment \\
\hline EM-004 & 6.91 & 1.55 & 1.75 & $210-\mathrm{Pb}$ & Sediment \\
\hline EM-005 & 22.55 & 16.30 & 2.25 & $210-\mathrm{Pb}$ & Sediment \\
\hline EM-006 & 38.18 & 16.30 & 2.75 & $210-\mathrm{Pb}$ & Sediment \\
\hline EM-007 & 53.82 & 16.30 & 3.25 & $210-\mathrm{Pb}$ & Sediment \\
\hline EM-008 & 69.45 & 16.30 & 3.75 & $210-\mathrm{Pb}$ & Sediment \\
\hline EM-009 & 85.09 & 30.00 & 4.25 & $210-\mathrm{Pb}$ & Sediment \\
\hline EM-0IO & 100.73 & 30.00 & 4.75 & $210-\mathrm{Pb}$ & Sediment \\
\hline EM-0II & 116.36 & 40.00 & 5.25 & $210-\mathrm{Pb}$ & Sediment \\
\hline EM-012 & 130.00 & 40.00 & 5.75 & $210-\mathrm{Pb}$ & Sediment \\
\hline EM-030 & 1180.00 & 30.00 & 14.75 & $14-C$ & Plant/Wood \\
\hline EM-06I & 1790.00 & 30.00 & 30.25 & $14-C$ & Plant/Wood \\
\hline EM-076 & 2360.00 & 45.00 & 37.75 & $14-C$ & Plant/Wood \\
\hline EM-085 & 2780.00 & 35.00 & 42.25 & $14-C$ & Plant/Wood \\
\hline EM-IIO & 3710.00 & 35.00 & 54.75 & $14-C$ & Plant/Wood \\
\hline BTY-Surf & -57.50 & 1.00 & 0 & & \\
\hline BTY-00I & -51.60 & 4.16 & 0.25 & $210-\mathrm{Pb}$ & Sediment \\
\hline BTY-002 & -49.91 & 4.12 & 0.75 & $210-\mathrm{Pb}$ & Sediment \\
\hline BTY-003 & -45.17 & 3.90 & 1.25 & $210-\mathrm{Pb}$ & Sediment \\
\hline BTY-004 & -41.09 & 2.85 & 1.75 & $210-\mathrm{Pb}$ & Sediment \\
\hline BTY-005 & -36.38 & 2.84 & 2.25 & $210-\mathrm{Pb}$ & Sediment \\
\hline BTY-006 & -31.31 & 3.65 & 2.75 & $210-\mathrm{Pb}$ & Sediment \\
\hline ВTY-007 & -25.63 & 4.46 & 3.25 & $210-\mathrm{Pb}$ & Sediment \\
\hline BTY-008 & -19.29 & 4.72 & 3.75 & $210-\mathrm{Pb}$ & Sediment \\
\hline BTY-009 & -11.52 & 4.99 & 4.25 & $210-\mathrm{Pb}$ & Sediment \\
\hline BTY-0IO & -3.09 & 5.44 & 4.75 & $210-\mathrm{Pb}$ & Sediment \\
\hline BTY-0II & 5.78 & 5.89 & 5.25 & $210-\mathrm{Pb}$ & Sediment \\
\hline BTY-0I2 & 14.14 & 6.74 & 5.75 & $210-\mathrm{Pb}$ & Sediment \\
\hline BTY-0I 3 & 23.88 & 7.59 & 6.25 & $210-\mathrm{Pb}$ & Sediment \\
\hline BTY-0I4 & 32.32 & 8.44 & 6.75 & $210-\mathrm{Pb}$ & Sediment \\
\hline BTY-0I5 & 40.12 & 9.29 & 7.25 & $210-\mathrm{Pb}$ & Sediment \\
\hline BTY-0I6 & 50.15 & 14.03 & 7.75 & $210-\mathrm{Pb}$ & Sediment \\
\hline BTY-0I7 & 60.70 & 18.77 & 8.25 & $210-\mathrm{Pb}$ & Sediment \\
\hline BTY-0।8 & 69.01 & 22.11 & 8.75 & $210-\mathrm{Pb}$ & Sediment \\
\hline BTY-0I9 & 79.7I & 25.46 & 9.25 & $210-\mathrm{Pb}$ & Sediment \\
\hline BTY-020 & 93.26 & 42.02 & 9.75 & $210-\mathrm{Pb}$ & Sediment \\
\hline BTY-02I & 106.66 & 58.59 & 10.25 & $210-\mathrm{Pb}$ & Sediment \\
\hline BTY-050 & 1005.00 & 30.00 & 24.75 & I4-C & Plant/Wood \\
\hline BTY-I57 & 6730.00 & 40.00 & 78.25 & $14-C$ & Plant/Wood \\
\hline ВTY- 189 & 8720.00 & 50.00 & 94.25 & I4-C & Plant/Wood \\
\hline BTY-220 & 9920.00 & 55.00 & 109.75 & $14-C$ & Plant/Wood \\
\hline BTY-240 & $11,600.00$ & 50.00 & 119.75 & I4-C & Plant/Wood \\
\hline
\end{tabular}

calibrated to calendar years using CALIB 6.0 (Stuiver and Reimer, 1993). All ages reported herein as 'ka' are calibrated ages in thousands of years before 1950 .

\section{Fossil diatom analysis}

Sub-samples were treated with $10 \% \mathrm{HCl}$ and $35 \% \mathrm{H}_{2} \mathrm{O}_{2}$ at room temperature to digest carbonate and organic material. Known 


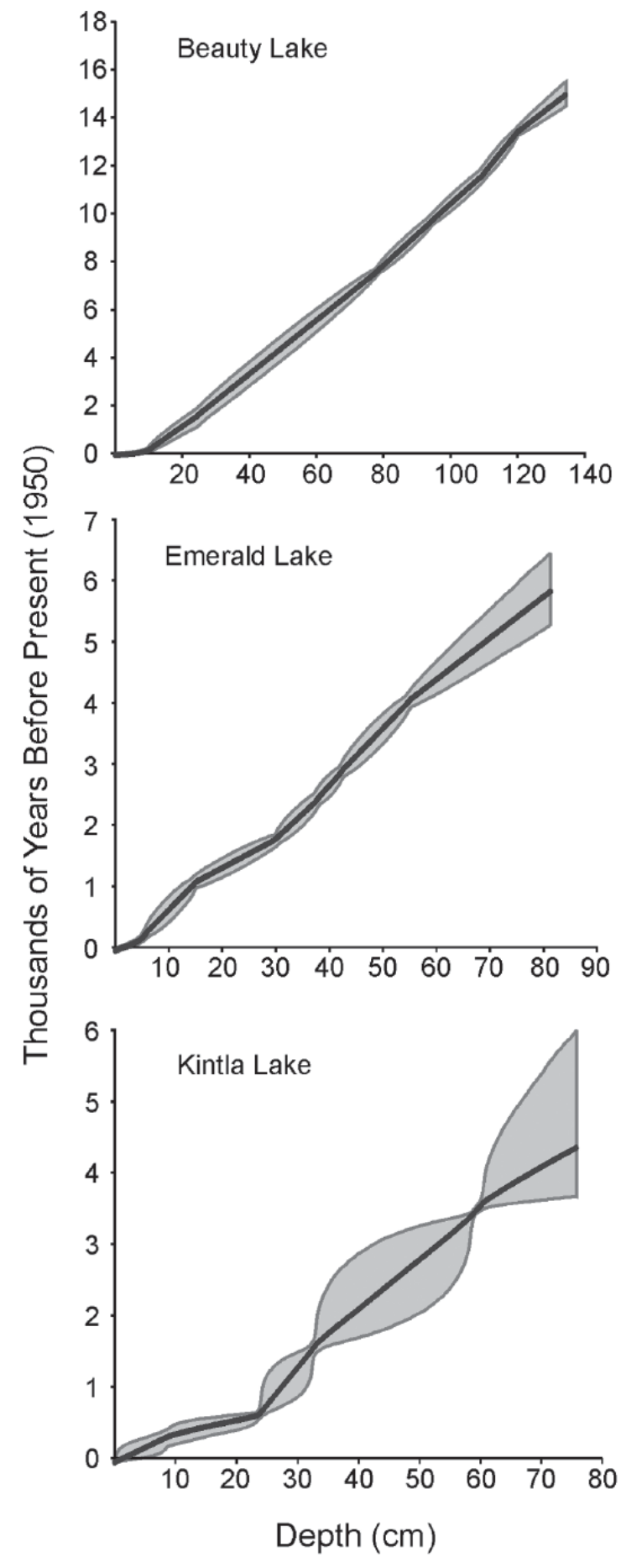

Figure 3. BACON age-depth models for Beauty, Emerald, and Upper Kintla Lakes. Gray envelope indicates $95 \%$ confidence.

quantities of polystyrene microspheres were added to estimate diatom concentrations (Battarbee, 2003); diatom extractions were dried onto coverslips and mounted in Zrax, a permanent highrefractive-index medium. Diatom frustules were identified to the most specific taxonomic level possible with $1000 \times$ magnification light microscopy using a Zeiss Axioskop 2 with Differential Interference Contrast optical illumination. When possible, at least 300 diatom valves were identified from each sample interval. The sediment core from Upper Kintla Lake was collected nearer to the shoreline, so planktic diatoms were typically a smaller component of the fossil assemblage. To adjust for this, a stratified counting technique was employed, where after 300 diatoms were identified, enumeration continued, ignoring benthic diatom forms until at least 100 planktic diatom valves were identified. All relative abundance data present herein from Upper Kintla Lake are reported as percentage of plankton. Data from Emerald and Beauty Lakes are presented as percentage of the total diatom assemblage. However, converting the datasets for these two lakes to percentage of plankton produced no significant changes in the diatom stratigraphy.

\section{Diatom-inferred stratification index}

Most Aulacoseira employ meroplanktic life strategies; they form long, heavy threadlike colonies that sink rapidly and encyst during stratified lake conditions (Jewson, 1992; Kilham, 1990). Aulacoseira lirata and Aulacoseira alpigena are a common component of deeper alpine and subalpine lakes with limited phosphorus concentrations and relatively high dissolved silica concentrations. As a result, these species typically are more successful in very well-mixed lake settings, where convective mixing in stratified lakes enhances the advection of nutrients from the hypolimnion and helps them to maintain their position in the photic zone (Carrick et al., 1993; Lund, 1954; Rühland et al., 2003).

Emerald and Beauty Lakes had fossil plankton diatom assemblages comprising the cyclotelloid species (Lindavia bodanica, Lindavia comensis, Discostella stelligera) that were the subject of experiments in Saros et al. (2012) and abundant populations of Aulacoseira species (A. lirata, Aulacoseira italica, A. alpigena). The only large-diameter cyclotelloid found in the fossil assemblages was $L$. bodanica; we inferred a relatively deep thermocline $(\sim 14 \mathrm{~m})$ from the presence of this species (Noble et al., 2013; Saros and Anderson, 2015; Saros et al., 2012). Small-diameter cyclotelloids, including the species D. stelligera, Lindavia ocellata, and L. comensis were present in the fossil diatom assemblages of these three lakes (Figure 4). Evidence suggests that in temperate regions these small-sized cyclotelloid species often out-compete other plankton when lakes are strongly stratified (Rühland et al., 2008; Saros and Anderson, 2015; Saros et al., 2012; Smol et al., 2005; Winder et al., 2009), and thus, we infer shallowest mixing depths when these species are abundant in fossil diatom assemblages.

Using this information together with the spectrum of optimal mixing depths (depth to the thermocline) resulting from ecological assay experiments for lakes that fit the appropriate nutrient criteria (Saros and Anderson, 2015; Saros et al., 2012), we created a Diatom-Inferred Stratification Index (DI-SI) that ranges from well mixed to strongly stratified for each of our three lakes. The DI-SI is based upon the concept that Aulacoseira species indicate a deeper state of mixing and a clearly higher trophic state than Lindavia (Cyclotella) in the instances where they occur in these lakes and that abundant $L$. bodanica indicates a deeper mixing state than when smaller cyclotelloid species such as $L$. comensis or L. ocellata are abundant. In the sediment record, the remains of these organisms occur together as assemblages, but taken as a whole they indicate the average stratification status of the lake through time.

The DI-SI we applied was a simple ratio expressed by the equation:

$$
\mathrm{DI}-\mathrm{SI}=\frac{\left(M_{\mathrm{k}}+1\right)}{\left(M_{\mathrm{j}}+1\right)}
$$

where $M_{\mathrm{k}}$ is the sum of the relative abundances of diatom species in the assemblage with the deepest inferred mixing depths and $M_{\mathrm{j}}$ is the sum of the species with the shallowest inferred mixing depths. The indices from all three records were standardized to average values over the record presented (Figure 5). A similar 
rationale and index (Smol et al., 2005; Wang et al., 2008, 2012) has been used previously to infer changes in the thermal structure of lakes. Non-parametric correlations between lakes were analyzed on resampled stratification index data using Spearman's rank correlation coefficient.

\section{Results}

The long-term patterns of the DI-SI are coherent between the lakes (Figure 5). Prior to $3.2 \mathrm{ka}$, the DI-SI was consistently less than 1 for all three lakes, indicating that species that fare better under stronger stratification dominated the plankton assemblages of each lake. In Emerald and Beauty Lakes, this is represented by the dominance of $D$. stelligera and in Upper Kintla Lake by elevated percentages of L. ocellata. Lower abundances of species preferring deeper mixing (Aulacoseira spp. and L. bodanica) are present throughout the records of all three lakes (Figure 4). Pairwise non-parametric correlations between each of the DI-SI records are statistically significant (Upper Kintla/Beauty: $\rho=0.31$, $p=0.0013$; Upper Kintla/Emerald: $\rho=0.78, p<0.0001$; Beauty/ Emerald: $\rho=0.44, p<0.0001$ ).

Between 3.2 and $\sim 2.3 \mathrm{ka}$, the records from all three lakes indicate periods of increasingly deeper lake mixing (Figure 5). Some minor discrepancies exist between the timing and degree of persistence in mixing depth state, which may be related to age model calculations, but the overall trend of increasing mixing depths (with respect to the previous period) exists for the records of all three lakes throughout this period (Figure 5). In the records from Emerald and Beauty Lakes, this change is represented by an increase in Aulacoseira species, replacing D. stelligera, whereas in the record from Upper Kintla Lake, L. ocellata is replaced by L. bodanica (Figure 4). From 2.3 to $1.4 \mathrm{ka}$, this trend gradually reverses for the records from all three lakes, when the relative abundances of the major planktic diatoms in the fossil assemblages show unilateral changes that are opposite to the prior transition.

After 1.4 ka all lake records show a return to enhanced stratification. With the exception of a few brief intervals, the DI-SI values return to values similar to the period prior to $3.2 \mathrm{ka}$ (Figure $5)$. For each record, modern DI-SI values match or exceed the lowest values from any time in the entire $4.5 \mathrm{ka}$ record. Overall, the DI-SI between the three lakes for the period after $1.4 \mathrm{ka}$ can be characterized as shallower mixing depths with slightly more variability. In all our lake records, the transitions observed in the DI-SI represent a shift in the dominance of the few species we selected, but it is worth noting that particularly after $1.4 \mathrm{ka}$, the records from Upper Kintla and Beauty Lakes also include the introduction of high relative abundances (up to $\sim 40 \%$ ) of some intermediate-sized Lindavia (Cyclotella) species (L. comensis and Lindavia rossii/tripartita), neither of which are a major constituent of the fossil diatom assemblages spanning back to $4.5 \mathrm{ka}$ (Figure 4). At Emerald Lake, there is a subtle, but important change as $D$. stelligera increases while Aulacoseira spp. decline, similar to the period prior to $3000 \mathrm{BP}$, but without A. italica.

\section{Discussion}

In all three lakes, the DI-SI at $4.5 \mathrm{ka}$ is fairly similar to the 20thcentury index within the same lake. Thus, with respect to the average depth of the upper mixed layer, the thermal structure of the lakes at $4.5 \mathrm{ka}$ was fairly similar to today. Between approximately 3.2 and $1.4 \mathrm{ka}$, an excursion toward significantly deeper mixing occurs in all three records (Figure 5). We interpret the regional coherence, in both timing and direction from these three lakes to indicate a shift in large-scale atmospheric circulation, specifically changes in the AL, as the driving force behind these changes. The elevation, basin morphometry, vegetation and soil development, aspect, and surface area between these three lakes differ substantially, but the lakes show remarkably similar patterns of inferred lake mixing over the late Holocene, suggesting a large-scale forcing mechanism.

Since few studies have explicitly explored changes in lake thermal structure over the Holocene, it is unclear exactly how these changes compare against other records in western North America. However, the general patterns of inferred changes in thermal structure of Upper Kintla, Beauty, and Emerald Lakes closely follow the pattern of the oxygen isotopic record of Jellybean Lake in western Canada (Anderson et al., 2005), which is inferred to track changes in moisture source associated with changes in the position and intensity of the AL through the Holocene (Figure 5). Pair-wise non-parametric correlations between the Rocky Mountain lake records and the record from Jellybean Lake indicate coherence in all cases $(\rho=0.47-0.57$ for pairwise comparisons between Jellybean Lake and each lake in this study, $p<0.0001$ in all cases). Anderson et al. (2005) suggested the period 4.5-3 ka represented a persistent intense state of the AL, similar to that experienced today, and that the period $\sim 3-1.2 \mathrm{ka}$ represented a weaker (or more westward position) AL. After $\sim 1.2$ $\mathrm{ka}$, the AL returned to a more eastward/intense state, but exhibited greater overall variability than previous periods. Our lake records show a change in thermal structure that may be driven by these same changes in the intensity and position of the AL through the Holocene, and they demonstrate that the influence of the AL may be responsible for broadly coherent Holocene patterns in lake records across parts of western North America.

Based on modern atmospheric circulation patterns, a persistently weakened AL would enhance upper atmosphere westerly flow into the Rocky Mountain region throughout winter and spring, which would result in increased cool season precipitation (Overland et al., 1999; Rodionov et al., 2005). We expect this would have two compound and synergistic effects on the thermal structure of lakes in this region. First, enhanced storm activity through the winter months would increase the total snowfall. A thicker snow bed over lake ice results in a higher albedo for the lake surface and typically acts to extend the ice cover duration (Ragotzkie, 1978). Over long periods this would result in a net loss of heat storage in the lake and act to weaken the average stratification strength by decreasing the total seasonal irradiance to which epilimnetic waters are exposed. For phytoplankton, whose seasonal succession patterns are substantially influenced by stratification and its influence on the nutrient cycle in lakes, this probably means a truncation of the stratification cycle, with fewer days of highly stratified epilimnetic water in the late summer. Second, increased storm activity through the spring would increase average near-surface wind intensity. Since stratification depth is primarily controlled by a combination of irradiance, light penetration, and wind intensity (Blenckner et al., 2007; Kirillin, 2003; Kirillin et al., 2012; Tanentzap et al., 2008), these changes should result in a change in how deeply the lakes mix. More intense wind in the spring would delay onset of lake stratification, creating a prolonged spring-like condition for the lake. Aulacoseira have a demonstrated relationship between wind speed and total production (Carrick et al., 1993), and enhanced near-surface wind speeds would also likely result in greater total productivity for deeper mixing species.

In clear lakes, with a small surface area $(<500$ ha $)$, locally driven changes in transparency resulting from variability in dissolved organic matter can have a large influence on thermal structure (Fee et al., 1996; Houser, 2006; Snucins and Gunn, 2000). Since temperature and precipitation can impact the influx of dissolved organic matter, this may explain some of the minor differences between the timing of transitions between lakes. However, Upper Kintla Lake is considerably larger, deeper, and at a substantially lower elevation than Beauty and Emerald Lakes, yet 
shows the same general pattern over the last $4.5 \mathrm{ka}$. There appears to be a stronger correlation between Emerald and Upper Kintla Lakes than between Emerald and Beauty Lakes (Figure 5.), which are much closer to each other. We believe this is explained by the differences in wind exposure between the three sites; Upper Kintla is located in a long narrow valley where wind intensity can
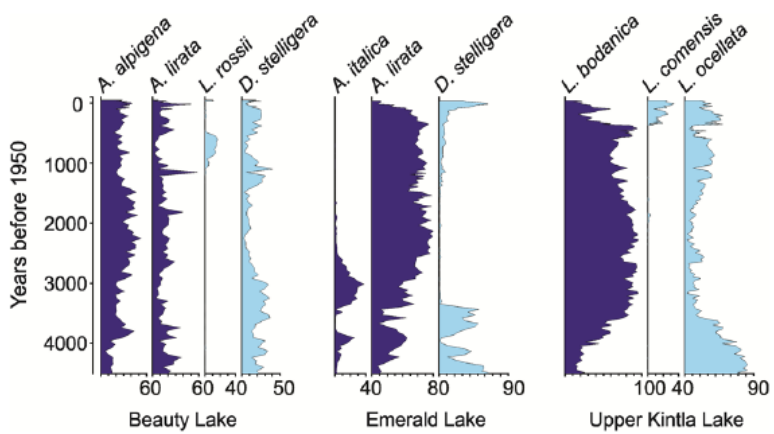

Figure 4. Stratigraphic profiles of the fossil diatom plankton of Emerald, Beauty, and Upper Kintla Lakes, plotted as relative abundances, for the past $4.5 \mathrm{ka}$. Stratigraphic columns are shaded from dark to light based on the relative inferred mixing depth of the diatom species. Note that Upper Kintla Lake values are based on stratified counts of planktic diatoms. be quite high along the long axis of the lake, and Emerald Lake is located high in the Beartooth Mountains with few trees to limit exposure to wind. In contrast, Beauty Lake is located in a more protected valley site.

Over the last century, the multi-decadal frequency of the AL, as expressed by the NPI, is nearly identical to frequency of the PDO (Miller et al., 2004; Minobe, 1999), which has been cited as a major influence on effective moisture in the region. Evidence of greatly increased effective moisture matching the timing of the inferred weakening of the AL $(\sim 3 \mathrm{ka})$ from the Jellybean Lake record exists in the lake records from Foy and Jones Lakes (Figure 2), located near our study sites (Shapley et al., 2009; Shuman et al., 2009). These studies infer major changes in water chemistry and rising lake levels after $3 \mathrm{ka}$, with conditions close to those of the modern climate after $1.4 \mathrm{ka}$. Throughout the Pacific Northwest, widespread glacial advances in alpine settings begin around 3 ka (Osborn and Luckman, 1988; Walker and Pellatt, 2008). Enhanced winter and spring precipitation in the Rocky Mountain region, as might be expected from a weakened AL, would create ideal conditions for glacial advances.

\section{Conclusion}

Our findings demonstrate the utility and strength of pairing diatom neoecological experiments with paleoecological studies within the same lake to improve our ability to interpret paleolimnological records. Despite significant differences in basin

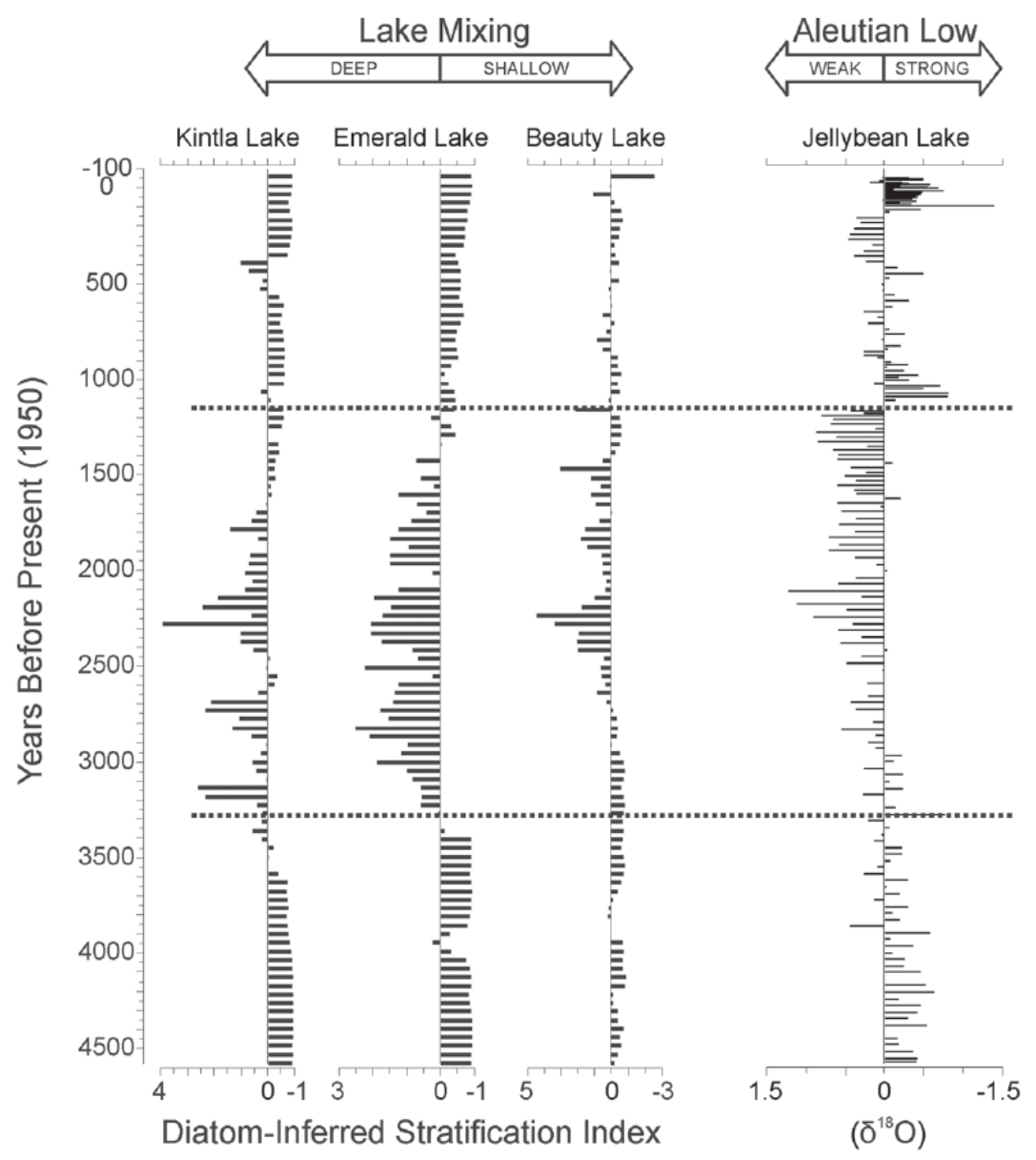

Figure 5. Diatom-Inferred Stratification Index (DI-SI) for Emerald, Beauty, and Upper Kintla Lakes plotted as standardized values $(0=$ average mixing depth for each lake) compared with the $\delta^{18} \mathrm{O}$ anomaly for Jellybean Lake (Anderson et al. 2005). The dotted lines mark major transitions in the inferred relative depth of mixing and corresponding changes in the position of the Aleutian Low as inferred from changes in the $\delta^{18} \mathrm{O}$ from the Jellybean Lake record. There appears to be a strong relationship between the weakened (westward positioned) Aleutian Low and deep mixing of the lakes between 3.2 and 1.4 ka. 
morphology and elevation, we have used these techniques to extract a simple, yet robust index from a complex diatom paleoecological dataset, which has allowed us to identify three distinct, regionally coherent periods in the late Holocene thermal structure. These periods broadly correspond to reconstructed patterns of the AL from independent records and suggest a widespread influence of the AL over winter wind intensity and precipitation patterns in the late Holocene throughout the Rocky Mountain region. This technique likely holds great promise for using phytoplankton from lake records to reconstruct past changes in lake thermal structure and potentially other major modes of atmospheric circulation. Through careful site selection, this approach has the potential to reconstruct long-term changes in wind intensity, air temperature, and lake-ice phenology.

\section{Acknowledgements}

We thank the following people for field assistance: KS Westover, AB Nurse, A Bamberg, E Wilcox, C Kissman, and CR Wigdahl. $\mathrm{S}$ Wooden assisted with lab processing of the diatom slides. Lab preparations and microscope analyses were performed at the Fritz Lab (University of Nebraska-Lincoln). We thank the following people for discussion and comments that improved the manuscript: CR Wigdahl, KE Strock, and K Slemmons. This draft manuscript is distributed solely for purposes of scientific peer review. Its content is deliberative and predecisional, so it must not be disclosed or released by reviewers. Because the manuscript has not yet been approved for publication by the U.S. Geological Survey (USGS), it does not represent any official USGS finding or policy.

\section{Funding}

Funding for this work was provided by the US National Science Foundation Division of Environmental Biology Program (Grant \#DEB-0734277). Any use of trade, firm, or product names is for descriptive purposes only and does not imply endorsement by the US Government.

\section{References}

Adrian R, O'Reilly CM, Zagarese H et al. (2009) Lakes as sentinels of climate change. Limnology and Oceanography 54(6): 2283-2297.

Adrian R, Wilhelm S and Gerten D (2006) Life-history traits of lake plankton species may govern their phenological response to climate warming. Global Change Biology 12(4): 652-661.

Anderson L, Abbott MB, Finney BP et al. (2005) Regional atmospheric circulation change in the North Pacific during the Holocene inferred from lacustrine carbonate oxygen isotopes, Yukon Territory, Canada. Quaternary Research 64(1): 21-35.

Appleby PG and Oldfield F (1978) The calculation of lead-210 dates assuming a constant rate of supply of unsupported ${ }^{210} \mathrm{~Pb}$ to the sediment. CATENA 5(1): 1-8.

Barron JA and Anderson L (2011) Enhanced Late Holocene ENSO/PDO expression along the margins of the eastern North Pacific. Quaternary International 235(1-2): 3-12.

Battarbee RW (2003) Diatom analysis. In: Berglund BE and Ralska-Jasiewiczowa M (eds) Handbook of Holocene Palaeoecology and Palaeohydrology. Caldwell, NJ: Blackburn Press, pp. 527-570.

Blaauw M and Christen JA (2011) Flexible paleoclimate agedepth models using an autoregressive gamma process. Bayesian Analysis 6: 457-474.

Blenckner T (2005) A conceptual model of climate-related effects on lake ecosystems. Hydrobiologia 533(1-3): 1-14.

Blenckner T, Adrian R, Livingstone DM et al. (2007) Large-scale climatic signatures in lakes across Europe: A meta-analysis. Global Change Biology 13(7): 1314-1326.
Carrick HJ, Aldridge FJ and Schelske CL (1993) Wind influences phytoplankton biomass and composition in a shallow, productive lake. Limnology and Oceanography 38(6): 1179-1192.

Cayan DR, Dettinger MD, Diaz HF et al. (1998) Decadal variability of precipitation over western North America. Journal of Climate 11: 3148-3166.

Chhak KC, Di Lorenzo E, Schneider N et al. (2009) Forcing of low-frequency ocean variability in the Northeast Pacific. Journal of Climate 22(5): 1255-1276.

Chipman ML, Clegg BF and Hu FS (2012) Variation in the moisture regime of northeastern interior Alaska and possible linkages to the Aleutian Low: Inferences from a late-Holocene $\delta^{18} \mathrm{O}$ record. Journal of Paleolimnology 48(1): 69-81.

Dröscher I, Patoine A, Finlay K et al. (2009) Climate control of the spring clear-water phase through the transfer of energy and mass to lakes. Limnology and Oceanography 54(6, Pt. 2): 2469-2480.

Edwards ME, Mock CJ, Finney BP et al. (2001) Potential analogues for paleoclimatic variations in eastern interior Alaska during the past 14,000yr: Atmospheric-circulation controls of regional temperature and moisture responses. Quaternary Science Reviews 20(1-3): 189-202.

Fee EJ, Hecky RE, Kasian SEM et al. (1996) Effects of lake size, water clarity, and climatic variability on mixing depths in Canadian Shield lakes. Limnology and Oceanography 41(5): 912-920.

Fisher DA, Osterberg E, Dyke AS et al. (2008) The Mt Logan Holocene-late Wisconsinan isotope record: Tropical PacificYukon connections. The Holocene 18(5): 667-677.

Fisher DA, Wake C, Kreutz K et al. (2004) Stable isotope records from Mount Logan, Eclipse Ice Cores and nearby Jellybean Lake. Water cycle of the North Pacific over 2000 years and over five vertical kilometres: Sudden shifts and tropical connections. Géographie physique et Quaternaire 58(2-3): 337-352.

Fritz SC (1996) Paleolimnological records of climatic change in North America. Limnology and Oceanography 41(5): 882 889.

Fritz SC (2008) Deciphering climatic history from lake sediments. Journal of Paleolimnology 39: 5-16.

Fritz SC, Ito E, Yu Z et al. (2000) Hydrologic variation in the Northern Great Plains during the last two millennia. Quaternary Research 53(2): 175-184.

Gan TY (2000) Reducing vulnerability of water resources of Canadian Prairies to potential droughts and possible climatic warming. Water Resources Management 14: 111-135.

Gerten D and Adrian R (2001) Differences in the persistency of the North Atlantic Oscillation signal among lakes. Limnology and Oceanography 46(2): 448-455.

Honda M, Nakamura H, Ukita J et al. (2001) Interannual seesaw between the Aleutian and Icelandic Lows. Part I: Seasonal dependence and life cycle. Journal of Climate 14: 1029-1043.

Houser JN (2006) Water color affects the stratification, surface temperature, heat content, and mean epilimnetic irradiance of small lakes. Canadian Journal of Fisheries and Aquatic Sciences 63(11): 2447-2455.

Jewson DH (1992) Life cycle of a Stephanodiscus sp. (Bacillariophyta). Journal of Psychology 28: 856-866.

Jones PD, Osborn TJ and Briffa KR (1997) Estimating sampling errors in large-scale temperature averages. Journal of Climate 10: $2548-2568$

Jones PD, Osborn TJ and Briffa KR (2001) The evolution of climate over the last millennium. Science 292: 662-667.

Katsuki K, Khim B-K, Itaki T et al. (2009) Land-sea linkage of Holocene paleoclimate on the Southern Bering Continental Shelf. The Holocene 19(5): 747-756.

Kilham P (1990) Ecology of Melosira Species in the Great Lakes of Africa. In: Tilzer MM and Serruya C (eds) Large Lakes: 
Ecological Structure and Function. Berlin: Springer-Verlag, pp. 414-427.

Kirillin G (2003) Modelling of the shallow lake response to climate variability. In: Terzhevik AY (ed.) Proceedings of the 7th Workshop on Physical Processes in Natural Waters. Petrozavodsk: Northern Water Problems Institute, Russian Academy of Sciences, pp. 144-148.

Kirillin G, Leppäranta M, Terzhevik A et al. (2012) Physics of seasonally ice-covered lakes: A review. Aquatic Sciences 74(4): 659-682.

Laird KR, Cumming BF, Wunsam S et al. (2003) Lake sediments record large-scale shifts in moisture regimes across the northern prairies of North America during the past two millennia. Proceedings of the National Academy of Sciences of the United States of America 100(5): 2483-2488.

Laird KR, Michels A, Stuart C et al. (2007) Examination of diatom-based changes from a climatically sensitive prairie lake (Saskatchewan, Canada) at different temporal perspectives. Quaternary Science Reviews 26(25-28): 3328-3343.

Latif M and Barnett TP (1994) Causes of decadal climate variability over the North Pacific and North Atlantic. Science 266(5185): 634-637.

Livingstone DM (2008) A change of climate provokes a change of paradigm: Taking leave of two tacit assumptions about physical lake forcing. International Review of Hydrobiology 93(4-5): 404-414.

Lund JWG (1954) The seasonal cycle of the plankton diatom, Melosira Italica (EHR.) Kutz. Subsp. Subarctica O. Mull. Journal of Ecology 42(1): 151-179.

Magnuson JJ, Benson BJ and Kratz TK (1990) Temporal coherence in the limonology of a suite of lakes in Wisconsin, U.S.A. Freshwater Biology 23: 145-149.

Magnuson JJ, Benson BJ and Kratz TK (2004) Patterns of coherent dynamics within and between lake districts at local to intercontinental scales. Boreal Environmental Research 9: 359-369.

Magnuson JJ, Kratz TK, Benson BJ et al. (2006) Coherent dynamics among lakes. In: Magnuson JJ, Kratz TK and Benson BJ (eds) Long-Term Dynamics of Lakes in the Landscape: LongTerm Ecological Research on North Temperate Lakes. New York: Oxford University Press, pp. 89-106.

Miller AJ, Chai F, Chiba S et al. (2004) Decadal-scale climate and ecosystem interactions in the North Pacific Ocean. Journal of Oceanography 60(1): 163-188.

Minobe S (1999) Resonance in bidecadal and pentadecadal climate oscillations over the North Pacific: Role in climatic regime shifts. Geophysical Research Letters 26(7): 855-858.

Noble PJ, Chandra S and Kreamer DK (2013) Dynamics of phytoplankton distribution in relation to stratification and winter precipitation, Fallen Leaf Lake, California. Western North American Naturalist 73(3): 302-322.

Nõges P, Nõges T and Laas A (2010) Climate-related changes of phytoplankton seasonality in large shallow Lake Võrtsjärv, Estonia. Aquatic Ecosystem Health \& Management 13(2): 154-163.

Ólafsdóttir KB, Geirsdóttir Á, Miller GH et al. (2013) Evolution of NAO and AMO strength and cyclicity derived from a 3-ka varve-thickness record from Iceland. Quaternary Science Reviews 69: 142-154.

Osborn G and Luckman BH (1988) Holocene glacier fluctuations in the Canadian Cordillera (Alberta and British Columbia). Quaternary Science Reviews 7: 115-128.

Overland JE, Adams JM and Bond NA (1999) Decadal variability of the Aleutian Low and its relation to high-latitude circulation. Journal of Climate 12(5): 1542-1548.

Pederson GT, Betancourt JL and McCabe GJ (2013) Regional patterns and proximal causes of the recent snowpack decline in the Rocky Mountains, U.S. Geophysical Research Letters 40: 1811-1816.

Ragotzkie RA (1978) Heat budgets of lakes. In: Lerman A (ed.) Lakes: Chemistry, Geology, Physics. New York: SpringerVerlag, pp. 1-19.

Rodionov SN, Bond NA and Overland JE (2007) The Aleutian Low, storm tracks, and winter climate variability in the Bering Sea. Deep Sea Research Part II: Topical Studies in Oceanography 54(23-26): 2560-2577.

Rodionov SN, Overland JE and Bond NA (2005) Spatial and temporal variability of the Aleutian climate. Fisheries Oceanography 14(s1): 3-21.

Rühland KM, Paterson AM and Smol JP (2008) Hemisphericscale patterns of climate-related shifts in planktonic diatoms from North American and European lakes. Global Change Biology 14: 1-15.

Rühland KM, Smol JP and Pienitz R (2003) Ecology and spatial distributions of surface-sediment diatoms from 77 lakes in the subarctic Canadian treeline region. Canadian Journal of Botany 81: 57-73.

Saros JE and Anderson NJ (2015) The ecology of the planktonic diatom Cyclotella and its implications for global environmental change studies. Biological Reviews 90(2): 522-541.

Saros JE, Interlandi SJ, Wolfe AP et al. (2003) Recent changes in the diatom community structure of lakes in the Beartooth Mountain Range, U.S.A. Arctic, Antarctic, and Alpine Research 35(1): 18-23.

Saros JE, Rose KC, Clow DW et al. (2010) Melting Alpine glaciers enrich high-elevation lakes with reactive nitrogen. Environmental Science \& Technology 44(13): 4891-4896.

Saros JE, Stone JR, Pederson GT et al. (2012) Climate-induced changes in lake ecosystem structure inferred from coupled neo-and paleo-ecological approaches. Ecology 93(10): 21552164.

Schneider N and Cornulle BD (2005) The forcing of the Pacific Decadal Oscillation. Journal of Climate 18: 4355-4374.

Shapley MD, Ito E and Donovan JJ (2009) Lateglacial and Holocene hydroclimate inferred from a groundwater flow-through lake, Northern Rocky Mountains, USA. The Holocene 19(4): 523-535.

Shuman B, Henderson AK, Colman SM et al. (2009) Holocene lake-level trends in the Rocky Mountains, U.S.A. Quaternary Science Reviews 28(19-20): 1861-1879.

Smol JP and Stoermer EF (2010) Applications and uses of diatoms: Prologue. In: Smol JP and Stoermer EF (eds) The Diatoms: Applications for the Environmental and Earth Sciences. Cambridge and New York: Cambridge University Press, pp. 3-7.

Smol JP, Wolfe AP, Birks HJB et al. (2005) Climate-driven regime shifts in the biological communities of arctic lakes. Proceedings of the National Academy of Sciences of the United States of America 102(12): 4397-4402.

Snucins E and Gunn J (2000) Interannual variation in the thermal structure of clear and colored lakes. Limnology and Oceanography 45(7): 1639-1646.

Stevens LR, Stone JR, Campbell J et al. (2006) A 2200-yr record of hydrologic variability from Foy Lake, Montana, USA, inferred from diatom and geochemical data. Quaternary Research 65(2): 264-274.

Straile D and Adrian R (2000) The North Atlantic Oscillation and plankton dynamics in two European lakes - Two variations on a general theme. Global Change Biology 6: 663-670.

Straile D, Livingstone DM, Weyhenmeyer GA et al. (2003) The response of freshwater ecosystems to climate variability associated with the North Atlantic Oscillation. In: Hurrell JW, Kushnir Y, Ottersen G et al. (eds) The North Atlantic Oscillation: Climate Significance and Environmental Impact. Washington, DC: American Geophysical Union, pp. 263-279. 
Stuiver M and Reimer PJ (1993) Extended 14C data base and revised CALIB 3.0 14C age calibration program. Radiocarbon 35(1): 215-230.

Tanentzap AJ, Yan ND, Keller B et al. (2008) Cooling lakes while the world warms: Effects of forest regrowth and increased dissolved organic matter on the thermal regime of a temperate, urban lake. Limnology and Oceanography 53(1): 404-410.

Walker IR and Pellatt M (2008) Climate change and ecosystem response in the northern Columbia River basin - A paleoenvironmental perspective. Environmental Reviews 16: $113-140$

Wang L, Li J, Lu H et al. (2012) The East Asian winter monsoon over the last 15,000 years: Its links to high-latitudes and tropical climate systems and complex correlation to the summer monsoon. Quaternary Science Reviews 32: 131-142.

Wang L, Lu H, Liu J et al. (2008) Diatom-based inference of variations in the strength of Asian winter monsoon winds between
17,500 and 6000 calendar years B.P. Journal of Geophysical Research 113(D21): 1-9.

Webster KE, Soranno PA, Baines SB et al. (2000) Structuring features of lake districts: Landscape controls on lake chemical responses to drought. Freshwater Biology 43(3): 499-515.

Williams JW, Shuman BN, Bartlein PJ et al. (2010) Rapid, timetransgressive, and variable responses to early Holocene midcontinental drying in North America. Geology 38(2): $135-138$.

Williamson CE, Saros JE, Vincent WF et al. (2009) Lakes and reservoirs as sentinels, integrators, and regulators of climate change. Limnology and Oceanography 54(6): 2273-2282.

Winder M, Reuter JE and Schladow SG (2009) Lake warming favours small-sized planktonic diatom species. Proceedings of the Royal Society of London, Series B: Biological Sciences 276(1656): 427-435.

Wise EK (2012) Hydroclimatology of the US Intermountain West. Progress in Physical Geography 36(4): 458-479. 